\title{
THE NEW PROPOSAL FOR A UNIFORM REAL ESTATE MORTGAGE ACT
}

\author{
HAROLD L. REEVE*
}

The Subcommittee on Law and Legislation ${ }^{1}$ of the Central Housing Committee, ${ }^{2}$ consisting of officers of federal agencies having to do with governmental activities in the field of real property mortgages ${ }^{3}$ has drafted a proposed Uniform Real Property Mortgage Act. ${ }^{*}$ When it reaches final form the Committee expects to have it submitted to state legislatures for adoption. As presently drafted, the proposed act is being studied by the Real Property, Probate and Trust Section of the American Bar Association ${ }^{5}$ and by the National Conference of Commissioners on Uniform State Laws. ${ }^{B}$ The draft prepared is the result of extended studies and experience with foreclosures throughout all of the states. Compliance with a request to discuss it necessarily involves examination both of the broad questions of legislative policy involved and of the particular provisions of the latest draft of the proposed act.

The advent of the government into the business of mortgage lending ${ }^{7}$ and of insuring mortgages ${ }^{8}$ has brought into sharp focus the diversity of mortgage fore-

- LL.M. Member of the Illinois Bar. General Counsel, Chicago Title \& Trust Company. Author of Illinois Real Estate Law (1929) and Illinois Law of Mortgages and Foreclosures (1932).

${ }^{1}$ The Subcommittee is composed of general counsel to federal housing agencies and their alternates. The membership includes: Abner Ferguson (Chairman), Burton C. Bovard, FHA; James L. Dougherty (Vice-Chairman), Paul C. Akin, RFC Mortgage Co.; Pcyton R. Evans, H. J. Slaughter (Vicc-Chairman), FCA; Leon H. Keyserling, David L. Krooth, USHA; Monroc Oppenheimer, Albert H. Cotton, FSA; A. E. Denton, John J. O'Brien, Dept. of Justice. Horace Russell, former General Counsel, FHLBB, and David $A$. Bridewcll, his legal assistant, who formerly represented the FHLBB on the Subcommittec, served as chairman and sccretary, respectively, from December, 1935, when the Subeommittce was organized until June and August, 1938, when they resigned.

${ }^{3}$ The Central Housing Committee is composed of the highest executive officers of the federal agencies concerned with housing finance and construction.

${ }^{3}$ Federal agencies which make or have made real estate mortgage loans during the past five ycars are the Home Owners' Loan Corporation, Reconstruction Finance Corporation, Federal Land Banks, and Farm Security Administration (formerly Rescttlement Administration). Federal agencies, in addition to these, which are vitally interested in real estate mortgage lending are the Federal Home Loan Bank Board, Federal Savings and Loan Insurance Corporation, Federal Housing Administration; RFC Mortgage Company, and Farm Credit Administration.

- For vicws of the draftsmen as to the objectives, scope and merits of the proposed act, sce "Mortgage Law and Mortgage Lending" by Horace Russell, General Counsel, U. S. Building and Loan Lcague (formerly Gencral Counscl, FHLBB), and David A. Bridcwell, attorncy, Home Owners' Loan Corporation (Aug. 1938) 14 J. of Land \& Pub. Util. Econ. 301. Sce also (1938) 86 U. of Pa. L. Rev. 517.

'Committec on Real Property Financing, Mr. Horace Russell, Chairman.

${ }^{6}$ Uniform Property Acts Section, Mr. Wm. L. Eagleton of Peoria, Illinois, chairman of subiommittce particularly charged with consideration of the act.

isee note 3 , supra.

${ }^{8}$ Federal Housing Administration. 
closure laws throughout the country. No two state laws are alike. They differ in an infinite variety of details but the primary differences relate to the basic concept of a proper mortgage foreclosure proceeding and to the existence of a right of redemption from a mortgage foreclosure sale. In parts of the country the foreclosure of a mortgage bears a close resemblance to the action taken when a bank loan falls due and the collateral posted to secure the loan must be resorted to by sale. In these sections the procedure in brief consists of extra-judicial action by the mortgagee, involving a short notice, a public sale of the pledged real estate and the conveyance of title to the purchaser, with no right of redemption, or else a brief period for redemption by the mortgagor. Other parts of the country require foreclosure under the supervision of a court of equity with varying periods fixed by statute for redemption. Eighteen states now generally use power of sale, twenty-nine judicial action. ${ }^{9}$ Twenty-nine provide periods for redemption, varying between six months and two years; nineteen states provide no statutory redemption. ${ }^{10}$ Upon no commercial subject do state laws differ more widely. Each is the reflection of local experience and ideas. Whether it will be possible to substantially reconcile them remains to be seen, but the proposed act is aimed at that end.

\section{The Questions Involved}

Consideration of the act which has been drafted raises several fundamental questions. Is uniformity socially desirable? Is it politically feasible? No subject of legislation has deeper roots in the past or more complex problems in the present. None should be closer to the hearts of the people, or more potent politically, for the possibility of the mortgagor's loss of home or farm to the money lender casts some shadow of fear upon every mortgage transaction. But, assuming that an act can be drafted which will provide for such an obvious improvement over present procedures that it will receive general approbation, what specifically should it contain? Upon what theory should it be drawn? Should it be prepared upon the premise that mortgagees are high grade, fair, lenient lenders of money, to whom should be given the

\footnotetext{
- These statistics are taken from a tabulation shown by Map II in the article by Mr. Bridewell, The Effects of Defective Mortgage Laws on Home Financing, supra, at p. 547. Foreclosure by power of sale is shown to be generally used in New Hampshire, Massachusetts, Rhode Island, Maryland (except in Baltimore), Michigan, West Virginia, Virginia, Tennessee, North Carolina, Mississippi, Alabama, Georgia, Minnesota, South Dakota, Missouri, Texas, Colorado and California. Foreclosure by judicial action is shown to be generally used in Vermont, New York, Connecticut, New Jersey, Pennsylvania, Delawarc, South Carolina, Florida, Ohio, Indiana, Kentucky, Illinois, Wisconsin, Iowa, Arkansas, Louisiana, Oklahoma, Kansas, Nebraska, North Dakota, Montana, Wyoming, New Mexico, Arizona, Utah, Idaho, Washington, Oregon and Nevada. Maine, where foreclosure is generally by notice or publication, is not placed within either general classification, but it would appear that the validity of a power of sale mortgage has been recognized in that state. Washington, etc. Railroad Co. v. Canadian, etc. Cotton Mills Co., ro4 Me. 527, 72 Atl. 49I (1908). The tabulation shows that foreclosure by power of sale is permissible, but not generally used, in Arkansas, Montana, Nevada, New York, Oklahoma, Wisconsin and Wyoming.

${ }^{10}$ These statistics relating to redemption periods have been taken from a tabulation shown by Map III at p. 548 in the same article cited in the preceding note. The only states where no provisions for redemption are made are shown to be Texas, Louisiana, Mississippi, Florida, Georgia, South Carolina, North Carolina, Virginia, West Virginia, Ohio, Maryland, Delaware, Pennsylvania, New Jersey, New York, Connecticut, Rhode Island, Massachusetts, and New Hampshire. California is shown to provide 12 months redemption if court action is used.
} 
power of quickly and effectively resorting to the pledged real estate with the expectation that, if a mortgage can be foreclosed promptly and cheaply with the minimum opportunity for the mortgagor to cause delay or create a nuisance value, then mortgagees can and will be more lenient than they have been? Or should it be drafted upon the theory that there are so many mortgages upon residential, agricultural and commercial properties throughout the country that they affect the economic wellbeing of the nation to the extent that it is socially desirable that all foreclosures be under the charitable mantle of courts of equity? Should the view prevail that equitable foreclosures afford mortgagors needed protection, result in mortgagees obtaining merchantable titles, and are less subject to attack than extra-judicial foreclosure proceedings, and that therefore the protection and stability gained through court supervision and decree is worth what it costs? Should such an act provide that the foreclosure of a home or farm shall be of the same summary character as the foreclosure of a speculative, highly financed commercial property owned by a building corporation having no other assets, or should different remedies be provided as to different classes of property? Should it recognize a conveyance of the title to the mortgaged premises to the mortgagee, the conveyance to be defeated only by payment of the debt, or should it authorize the mortgagee to sell the mortgaged premise's in the event of default? Should it provide for a strict foreclosure proceeding, or limit all foreclosures to actions in equity? And should a mortgage transaction be viewed and treated as a purely. commercial transaction, or should it be clothed with the traditional leniency which has been characteristic of mortgage transactions through centuries of human experience? These and a host of other social, economic and political questions are inherent in the problem of drafting or considering any mortgage foreclosure legislation. They are complicated by self-interest, sectional differences of view, tradition and the adherence of most people to that with which they are familiar.

The draftsmen of the proposed uniform act have sought to solve these problems by providing for an extra-judicial foreclosure under power of sale to be contained in the mortgage, with a thirty-day redemption period. The act drafted is lengthy, containing over thirty sections. It covers the form of mortgage, the meaning of words, and procedures to be followed, all in greatest detail. A study of it requires consideration of the relation it bears to what has gone before in the field of mortgage law, of how it will operate if adopted, and of whether it is likely to be considered as such a reasonable solution of an age-old problem as to be generally acceptable.

\section{Foraser Attempts to Find a Solution}

Historically, the pendulum of ideas as to mortgages and their foreclosure has swung slowly from side to side over a period of many centuries, first to give the mortgagee the maximum power, then to give the mortgagor the greatest leniency, again to the mortgagee, again to the mortgagor. From Old Testament times to modern moratoria, it has kept up its swing, for mortgage foreclosure law has ever 
been a series of encounters between mortgagees, desiring a simple, quick and direct means of taking over the security, and mortgagors seeking to redeem homes and farms and to have mortgages impressed with attributes of leniency unknown in other business transactions. In these encounters the mortgagors ultimately have generally been able to hold their own, and very early in recorded history mortgages had acquired peculiar qualities which continue to be found in principle in most parts of the country today.

In Nehemiah we read: "Some also there were that said, We have mortgaged our lands, vineyards and houses, that we may buy corn, because of the dearth."11 Even in those times leniency toward the mortgagor had manifested itself. It appears that under the Jewish law, which was designed to encourage and protect people in agricultural pursuits, an owner was powerless to convey or mortgage his lands beyond the next jubilee, which occurred every fifty years. The mortgagor could redeem at any time before the jubilee, and in any event when the day of the jubilee arrived the mortgage debt was discharged by operation of law..$^{12}$

This tendency of leniency toward the mortgagor later found expression in Roman law. Under the Roman hypotheca, where possession remained with the debtor, failure to pay the debt at the stipulated time was not permitted to work a forfeiture of the property as against the debtor. Express agreements that the property pledged should pass to the creditor without sale or appraisement or that the debtor should forfeit his right of redemption if he did not pay at the date specified, were declared illegal and void by an edict of Constantine. ${ }^{13}$ Some writers have indicated that the Roman creditor could not enforce his security except by sale under decretal order of court. ${ }^{14}$ It seems probable, however, that the creditor was permitted to foreclose by the exercise of a power of sale, without a judicial decree, after giving due notice of the sale to the debtor. But where the debtor could not be found and notice of the sale could not be given to him, a decretal order was necessary. ${ }^{15}$ In fact, it seems that two notices to the debtor were required, one a notice to pay the debt, and the other, notice of foreclosure sale. ${ }^{16}$ The creditor could not purchase at his own foreclosure sale, directly or indirectly, and a sale by the creditor "presupposed that the creditor had either obtained a judgment against the debtor, or at least had notified the latter of his intention to sell, and had waited two years after such notice."17

Under the English common law the mortgage was at first a pledge of land, usually requiring a judgment to complete the transfer of title and to vest it in the mortgagee. ${ }^{18}$ However, the pendulum early began swinging the other way, the

12 Nehemiah, c. 5 , v. 3 .

18 Bacon's Abridgment (Mortgage [A]); I Jones, Mortgages (8th ed. 1928) $5 \mathrm{I}$.

${ }^{73}$ MACkeldex, Civil Law (2d Am. ed. 1849) \$349, and footnote.

"Bacon's Abridgaient (Mortgage [A]); I Coote, Mortgages (8th ed. I9I2) c. II, §ii, p. 8.

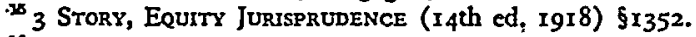

${ }^{20}$ MARKBY, ELEMENTS OF LAw (6th ed. 1905) $\$ 456$.

${ }^{17}$ Mackeldey, Civit Law $\$ 350$, footnote p. 385 .

Iu Lightcap v. Bradley, 186 Ill. 510, 58 N. E. 221, 223 (1900); Chaplin, The Story of Mortgage Law (1890) 4 Harv. L. Rev. 7 . 
interests of the mortgagee soon gained ascendancy, and the law became "stern and unrelenting."19 A mortgage was treated as vesting title in the mortgagee and the mortgagee became the owner of the mortgaged lands though his title was liable to be defeated upon the happening of a condition subsequent, namely, the payment of the mortgage debt on the day specified. But if the debt was not paid when due, the transaction was ended and the mortgagor was through. No foreclosure was re-. quired. No right of redemption existed. From the limited viewpoint of low cost of realizing upon the security, and of simple, efficient and speedy acquisition of the mortgaged premises by the mortgagee, no subsequent method has equalled the procedure then used, but the harsh efficiency of the system was its own undoing. While it lasted the mortgagee was entitled at all times to the possession of the mortgaged premises, and unless he had expressly agreed that the mortgagor might remain in possession, he was entitled to maintain ejectment against the mortgagor and secure possession of the mortgaged premises even before there was any default under the mortgage. The time fixed for payment of the debt was called the "law day" and unless the mortgagor paid at the day stipulated, the title of the mortgagee at once became absolute and indefeasible, and the mortgagor ceased to have any right or interest in the estate. 20 Literally, mortgage means a "dead pledge,"21 and Littleton, expounding the English common law view, explained this terminology by pointing out that "the cause why it is called mortgage is, for that it is doubtful whether the feoffer will pay at the day limited such sum or not; and, if he doth not pay, then the land which is put in pledge upon condition for the payment of the money is taken from him forever, and so dead to him upon condition. And if he doth pay the money, then the pledge is dead as to the tenant."22

After a time social repercussions started the pendulum again swinging back in favor of the mortgagor. The English courts of equity espoused the mortgagor's cause and reverted to some of the equitable principles which had been part of the Roman law. ${ }^{23}$ The chancellors refused to follow the common law doctrine of absolute forfeiture if the mortgagor failed to pay on the "law day," and instead held that in equity the mortgagor was still entitled to redeem notwithstanding breach of the condition at law. This right became known as the "equity of redemption." While courts of equity could not alter the legal effect of the forfeiture of the estate at common law on breach of the condition of the mortgage, they succeeded, as Mr. Chief Justice Hughes has phrased it, in "operating on the conscience of the mortgagee," 24 maintaining "that it was unreasonable that he should retain for his own benefit what was intended as a mere security; that the breach of condition was in the nature of

${ }^{10}$ Longwith v. Butler, 8 IIl. 32 ( 1845 ).

${ }^{3}$ Barrett v. Hinckley, 124 Ill. 32, 14 N. E. 863 (1888).

21 "Mort," dead, and "gage," pledge. ILitrleton's Tenures, lib. iii, c. 5, 5332.

$\approx$ "It will be conceded by all, who have any knowledge of the Roman law, that the equitable doctrines now universally prevailing in regard to mortgages, have been derived from that source. The civil law, in this as in many other instances, has been the great armory from which the courts of equity in England have supplied themselves with the most efficient weapons to ward off the severities of the stern and unrelenting common law." Longwith v. Butler, 8 IIl. 32,36 ( 1845 ).

"Home Building \& Loan Ass'n v. Blaisdell, 290 U. S. 398,446 (1934). 
a penalty, which ought to be relieved against, and that the mortgagor had an equity to redeem on payment of principal, interest and costs, notwithstanding the forfeiture at law. ... The equitable principle became firmly established and its application could not be frustrated even by the engagement of the debtor entered into at the time of the mortgage, the courts applying the equitable maxim 'once a mortgage, always a mortgage and nothing but a mortgage." "25 It was but a logical further step for courts of equity to treat the mortgagor as the owner of the land, subject only to a lien to secure the mortgage debt, and to hold that this interest or estate remaining in the mortgagor could be granted or devised by him, or reached by his creditors. ${ }^{26}$ Mr. Justice Mulkey said: "In short, the positions of mortgagor and mortgagee were substantially reversed in the view taken by courts of equity." encounter between mortgagee and mortgagor was that the civil law doctrine of leniency to the mortgagor, which formed the basis for the position of the English equity courts ${ }^{28}$ again gained ascendancy. The common law judges did not, however: yield willingly. Mr. Justice Story points out: "These doctrines of Courts of Equity were at first strenuously resisted, and found little public favor owing to the rigid character of the common law and the sturdy prejudices of its advocates. We are told by Lord Hale that in the Itth year of Richard II, Parliament would not admit of an équity of redemption; although it seems not long after to have struggled into existence. Even as late as the latter part of the region of Charles II, the same great judge was so little satisfied with encouraging an equity of redemption, that in a case before him for a redemption he declared that by the growth of equity on equity the heart of the common law is eaten out and legal settlements are destroyed. And perhaps the triumph of common sense over professional prejudices has never been more strikingly illustrated than in the gradual manner in which Courts of Equity have been enabled to withdraw mortgages from the stern and unrelenting character of conditions at the common law." 29

The doctrine of leniency toward the mortgagor, announced by the English courts of equity, has generally found expression in the United States. ${ }^{30}$ In many of the states, statutory periods after foreclosure have always existed within which the mortgagor may redeem. That the natural conflict in interest between the mortgagee and mortgagor is not confined to past history is well illustrated by the recent mortgage moratorium legislation enacted in many of the states, ${ }^{31}$ and by the provisions recently incorporated in the Federal Bankruptcy Act for the relief of debtors. ${ }^{32}$ There has

$z_{16 i d .}$

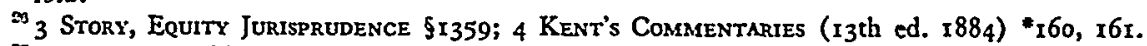

${ }^{27}$ Barrett v. Hinckley, 124 Ill. 32, I4 N. E. 863 (1888).

$\approx$ Longwith v. Butler, 8 ill. 32 (1845).

${ }^{20} 3$ Story, Equity Jurisprudence $\$ 1358$. See 4 Kent's Commentaries *x58, i59. Lotd Mansfield, a common law judge, sought to bring the common law into accord with the doctrine of the courts of equity, without success. MArkBy, ELEMENTS of LAw (6th ed. 1905) \$476.

${ }_{41}^{30}$ C. J. (1926) 275 (\$3).

an Poteat, State Legislative Relief for the Mortgage Debtor During the Depression, supra, p. 517.

${ }^{2} \$ 75(n)$ of the Bankruptey Act as amended in 1935 , II U. S. C. A. \$203(n), concerning agricultural compositions and extensions, provides: "In all cases where, at the time of filing the petition, the period of 
probably never been a more striking illustration of the pendulum's swing in favor of the mortgagor. Some of this legislation has gone so far in an attempt to show special leniency to the mortgagor that courts, at the instance of the mortgagee, have held it unconstitutional. . $^{33}$

This historical background emphasizes the difficulties involved in the drafting of a uniform mortgage act. The draftsman is confronted with the problem of balancing the interests of the mortgagee against those of the mortgagor, something that has always furnished a fertile subject for controversy, and of bringing forth a proposed act likely to meet with that degree of general approval necessary to uniform adoption. To accomplish this ultimate object, the proposed act must not only adequately protect the interests of the mortgagee but it must not call upon the mortgagor to surrender too much ground already gained. The latter seems particularly important because, if mortgagors voice objection, legislatures are likely to listen. Mortgngors include largely owners of homes and-farms, and the legislators who must be called upon ultimately to approve a proposed uniform mortgage act have consistently manifested a strong tendency to show special leniency to these classes of property owners.

The attempt to draft a uniform mortgage foreclosure law is not a new effort. The National Conference of Commissioners on Uniform State Laws studied and wrestled with the subject, gathered extensive data, and after many years of effort embodied their ideas in a proposed act. ${ }^{34}$ In IgIr, the Committee of the Conference then working on the subject reported to the Commissioners on Uniform State Laws that in view of the "conflict of law, custom, and procedure as to mortgages, their foreclosure and their release, your Committee is of opinion that the matter is too complicated and too subject to differences as to form and procedure in the various states for these Commissioners to undertake now to bring them into uniformity:"38 However, the Conference persisted and finally a draft was completed which was approved by the American Bar Association in $1927 .{ }^{36}$ To date, no state has adopted this proposed uniform act, ${ }^{37}$ and there has existed considerable doubt both as to the wisdom and the feasibility of uniformity in mortgage foreclosure law. The Conference presently has before it for consideration the draft here under discussion.

redemption has not or had not expired, or where the right under a deed of trust has not or had not become absolute, or where the sale has not or had been confirmed, or where deed had not been delivered, the period of redemption shall be extended or the confirmation of sale witheld for the period necessary for the purpose of carrying out the provisions of this section. The words 'period of redemption' wherever they occur in this section shall include any State moratorium, whether established by legislative enactment or executive proclamation, or where the period of redemption has been extended by a judicial decree."

${ }^{2}$ See, e.g., Travellers' Ins. Co. v. Marshall, I24 Tex. 45, 76 S. W. (2d) I007 (1934); Pennsylvania Co. for Insurances, etc. v. Scott, 329 Pa. 534, 198 Atl. II5 (1938); Louisville Joint Stock Land Bank v. Radford, 295 U. S. 555 (1935); Worthen Co. v. Kavanaugh, 295 U. S. 56 (1935). But cf. Wright v. Vinton Branch, 300 U. S. 440 (I937); Home Bldg. \& Loan Ass'n v. Blaisdell, 290 U. S. 398 (1934).

${ }^{*}$ Uniform Real Estate Mortgage Act of 1927 . For the text of the Act, with the Committee's report and notes, see Handbook, Nat. Conf. Comm'rs Unif. STate Laws, 1927, pp. 654-718.

${ }^{35} 6$ A. B. A. REp. 950 (IgII). ${ }^{80}$ A. B. A. REP. 402 (I927).

st Minnesota enacted 536 , providing a short form mortgage. Misw. Srat. (Mason, 1938 Supp.) $\$ \$ 8204-9 ; 9$ UNIf. Laws ANN. (Supp. 1937) 203 


\section{Objectives and General Method}

The objectives sought by the proposed act have been stated ${ }^{38}$ to be: $(\mathrm{I})$ to prevent injustices, from unconscionable excess judgments against the mortgagor, and otherwise; (2) to encourage the more liberal extension of credit at lower interest rates and on longer and more suitable terms, thereby stimulating home ownership; (3) to increase the maximum amount of a loan which a lending institution would be willing to advance; ${ }^{39}$ (4) to make it possible that in the event of misfortune overtaking the home owner mortgagor, the mortgagee will be able to extend greater leniency, thereby in many cases preventing ultimate foreclosure; ${ }^{40}$ (5) to make more accessible mortgage funds because the simplified procedure provided for in the act would facilitate the placing and handling of mortgages by large lending institutions operating on a nation-wide basis and the carrying out of the federal housing credit program; (6) to reduce foreclosure costs, which. in the end are paid by or charged against the mortgagor or his property; and ( 7$)$ to reduce the cost of drafting and recording mortgage instruments for which the mortgagor pays when he obtains a loan. ${ }^{41}$ In short, the objectives are to provide a more rapid and less expensive remedy for realization upon mortgage security than now exists in a number of the states where statutory redemption periods of a year or more are provided and where, in some instances, foreclosure can only be effected by suit in equity.

The method decided upon for accomplishing these objectives is foreclosure through the mortgagee's exercise of a "power of sale," limiting redemption by the mortgagor to a period thirty days after sale and imposing other limitation provisions which preclude the mortgagor from commencing a court attack upon the foreclosure proceedings unless he acts most promptly. ${ }^{42}$

${ }^{20}$ Report, dated May 14, I938, of Mr. Horace Russell to the Real Property, Probate and Trust Section of the American Bar Association, presented at the July, 1938, meeting at Cleveland.

${ }^{20}$ Russell and Bridewell, stapra note 4.

${ }^{\circ}$ Address by Mr. Horace Russell before the United States Building and Loan League at Los Angeles, Oct. 7, 1937 .

${ }^{41}$ Russell and Bridewell, supra note 4 :

10 The proposed act consists of seven articles. Brief reference is hereafter made to the substance of the various articles. The principal provisions of the important Article IV, dealing with foreclosure, are set out morc fully in the appendix, infra, p. 588.

Article I relates to the title of the act and definitions.

Article II relates to the application of the act. It provides that the act shall not apply to mortgages executed before it takes effect, although the "parties to any mortgage may agree, however, in a recorded writing that the provisions of this act shall apply to such mortgage." It is further provided that a power of sale contained in a mortgage executed after the effective date of the act cannot be enforced by any procedure other than that prescribed by the act, although "any mortgage may be foreclosed by the mortgagee at his option by court action."

Article III prescribes a short statutory form of mortgage. Following this form, various clauses appearing therein are declared, when used in any mortgage, to have extended meanings which are set forth in the act.

Article IV, consisting of $\$ \$ 30-38$ inclusive, deals with foreclosure. It provides for extra-judicial foreclosure by the exercise of a right of sale by the mortgagee and specifies the notice of sale to be given by the mortgagee, the procedure at the sale and the remedies available to the mortgagor. It also deals with confirmation of the sale, the certificate of sale (being the deed to the purchaser), deficiency judgments, costs and expenses, and attorneys' fees.

Article V contains certain general provisions. It provides that a mortgage does not give the mortgagee any right of possession, except upon conditions specified in the mortgage, or any right to rents and profits 


\section{Basic Questions of Legislative Policy}

The basic questions of legislative policy which are involved in consideration of changes in existing mortgage foreclosure laws relate to the type of foreclosure to be determined upon and to the existence or abolition of a period for redemption after foreclosure sale. Many other questions present themselves but these seem fundamențal.

\section{Type of Foreclosure Proceeding}

As to the merits of judicial foreclosures as against extra-judicial foreclosures, there always has existed sharp differences of view. A large majority of the states generally use judicial action. ${ }^{43}$ Illinois after many years of experience with foreclosures under powers abolished them and now by statute prohibits the sale of any real estate by virtue of any power of sale contained in a mortgage, ${ }^{44}$ but eighteen states generally use sales under power, although some others which have statutes authorizing sales under power generally use judicial action. ${ }^{45}$ Both systems have their warm adherents. ${ }^{48}$

unless such right is expressly provided by the mortgage. It provides for court appointinent of a receiver where the mortgaged premises are clearly inadequate security, or are in danger of being materially injured or reduced in value as security by removal, abandonment, destruction, deterioration, accumulation of prior liens, waste (legal or equitable) or otherwise. Subject to recording acts, a mortgage securing a negotiable instrument is declared to be free from any defenses from which the mortgage obligation is free by reason of its negotiable character. It is provided that where a mortgage secures a debt evideneed by several separate notes, the mortgage is for the equal security of all parts of the obligation regardless of time of delivery or maturity, transfer thereof, or otherwise, unless there is an express recorded agrecment fixing different priorities. Section 44 provides that future advances may be made on a mortgage up to the maximum amount set forth in such mortgage and such advances shall have the same priority with respect to other encumbrances as though such advances had been made at the time the mortgage was executed. Other provisions of Article $\mathrm{V}$ relate to foreclosure sales by the mortgagee's agent, under a recorded power of attorney; foreclosure sales by executors, administrators, or other personal representatives appointed in another state or county; substitution of trustees in mortgage trust decds; and rights of successors of mortgagees and purchasers. It is provided that appeals may be taken from final court orders in matters arising under the act, and that such appeals shall be governed by the laws of the state with respect to appeals in matters involving the title to real estate.

Article VI provides a statute of limitations upon mortgages. The limitation period is fixed at ten years from the maturity of an obligation secured by the mortgage, in the absence of extension agreement. Where the maturity of an obligation secured by a mortgage is not ascertainable from the record, the limitation period is fixed at fifty years from the date of the mortgage.

The final Article VII provides for liberal construction of the act, and contains separability and repeal clauses.

"See note 9, supra.

"Ill. Rev. Stat. (1937) c. 95, \$23.

is Sec note 9, supra.

${ }^{40}$ In 3 JONEs, Mortcages (8th ed. 1928) $\$ 2285$, that author, in pointing out the advantages of foreclosure by power of sale, details the steps involved in a foreclosure by court action, which he describes as "cumbersome and expensive" and says: "It is true that all these procedings are designed for the protection of the mortgagor and others who may be interested in the property; but while such protection is occasionally not without its use, in almost all cases the parties interested in the property are equally well protected by the remedy out of court afforded by a power of sale, and, as will be presently noticed, when protection is needed in exceptional cases the courts can be effectually appealed to." As far back as 1895 Mr. Justice Field quoted with approval the observations of Mr. Jones that "the delay and expense incident to a foreclosure and sale in equity have brought power of sale mortgages and trust deeds into general favor both in England and America, and although their general use is now confined to a part only of our States, the same influences which have already led to their partial adoption and use are likely to lead to their general use everywhere at an early day." Bell Mining Co. v. Butte Bank, 156 U. S. 470,478 
In favor of sales under powers it is often argued that experience in the states in which this mechanism has been employed shows it to be more satisfactory as a whole than any remedy yet devised. It also is frequently contended that court actions necessitate the expenditure of court costs, increase attorneys' fees, require unnecessary outlays for the fees of masters in chancery and receivers, add generally to the expense of foreclosing, and take too long because of procedural steps and congested court dockets, and that because sales under power without recourse to the courts are quicker, less cumbersome and cheaper, the latter are far better. These arguments against equitable foreclosures, however, are equally applicable in favor of any other procedure than court action. In fact, they are as pertinent in support of an argument in favor of the desirability of adopting the common law method of conveying the mortgaged premises to the mortgagee to be his unless the mortgage debt is paid as they are in the connection in which they are most frequently used. That there is room for improvement in equitable foreclosure proceedings is not, in fact, a convincing argument in favor of any other particular remedy.

In the absence of contest, sales under power usually are quicker than equitable foreclosures and they should cost less. On the other hand it may be argued that these advantages are offset by the fact that courts are quick to scrutinize such sales for irregularities and to grant relief as against harsh conduct or inequitable situations even where only slight irregularities or improper action have occurred. ${ }^{47}$ Lawyers examining titles flowing from sales under powers are required to exercise an experienced and nice judgment in determining which departures from a perfect compliance with the letter of the law may be passed over and which must be viewed with alarm or be ratified by a court decree in an action in which all interested parties are brought within the jurisdiction of the court.

Under some authorities, even a bona fide purchaser for value of lands coming through a foreclosure by exercise of power of sale may find that he has failed to acquire any title because of defects said to render the proceedings "void," as distinguished from merely irregular, and this notwithstanding the fact that the record of the proceedings appears entirely regular on its face. Thus in a Massachusetts case, the court, after pointing out that title coming through such a proceeding appeared by the record "to be a good, absolute title," further said: "On principle, we think it

(1895). Sce also the opinion of the Supreme Court of Montana in the same case: 8 Mont. 32, I9 Pac. 403, $4 \mathrm{II}, 4 \mathrm{I2}$ (1888). However, in I Wiltsie, Mortgnge Foreclosure (4th ed. 1927) $\$ 333$, 34, that author, referring to foreclosure by power of sale, says: "The procedure is generally simple and cheap, but not so quick and certain in results as an equitable action. Being statutory it is extremely technical and liable to produce defective titles." And speaking of foreclosure by equitable action, he continues: "It is the most direct and certain practice, affords the largest opportunities for the adjustment and enforcement of the rights of all parties interested, is the quickest in final results, produces the strongest and firmest titles, and does the greatest justice to both mortgagor and mortgagee."

" 3 Jones, Mortgnges $\$ 2330$ et seq., \$2451 et seq. Smith, J., in Soule v. Ludlow, 3 Hun 503 (N. Y. I875), says: "Relief will be given by suit to set aside foreclosure proceedings by advertisement, whenever by any fraud, mistake, deceit, or unfair contrivance or practice or bad faith, in conducting the proceedings of the foreclosure or sale, the rights of the mortgagor or of subsequent incumbrancers have been injuriously affected upon pretty much the same grounds as the court would recognize as sufficient for opening the sale if the foreclosure had been by action." 
must be considered in this commonwealth, a mortgagee, when there has been no default or breach of the conditions of the mortgage, cannot sell the land mortgaged under the usual power of sale contained in a mortgage, so as to pass a good title even to a bona fide purchaser for value, or to any subsequent purchaser from him."18 Even a remote purchaser under such circumstances may find that he has purchased at his peril and acquired no title, although the invalidating defect is a latent one not ascertainable from the public records. On the other hand, the general rule is that a third party purchasing lands in good faith and for value may. safely rely upon a foreclosure decree entered by a court of equity if it appears from the record of the proceedings that the court had jurisdiction. ${ }^{49}$

It is true that property wrongfully sold through foreclosure by exercise of power of sale may pass into the hands of a bona fide purchaser so as to defeat the mortgagor's right to have the conveyance and sale set aside in equity. ${ }^{50}$ But it is also true that a third party may under certain circumstances acquire a good title, free from attack, where he purchases in good faith in reliance upon an erroneous foreclosure decree. ${ }^{51}$

An argument frequently raised in favor of equitable foreclosures is that they grant greater protection to mortgagor, mortgagee and to the purchaser at the sale; to the mortgagor by safeguarding his rights, permitting him to interpose his defenses, if any, and through the court's exercise of its chancery jurisdiction in connection with approving or disapproving the foreclosure sale, and otherwise, to prevent inequity or injustice; to the mortgagee through the exercise of its powers to enforce the terms of the mortgage, sequester income, prevent waste and cause the mortgagor to do justice; and to the purchaser by putting him in a position where he acquires good title to the mortgaged premises. In a foreclosure in a court of equity the foreclosure decree may bar mortgages and leases executed subsequent to the mortgage being foreclosed, and other encumbrances and interests found to be subordinate to the mortgage foreclosed, where such issues have been adjudicated under proper pleadings and where proper parties have been brought before the court. ${ }^{62}$ In a sale

${ }^{49}$ Rogers v. Barnes, 169 Mass. 179, 47 N. E. 602 (1897). And see also Crowley v. Adams, 226 Mass. 582, II6 N. E. 241 (19r7); Redmond v. Packenham, 66 Ill. 434 (1872); Huntington v. Crafton, 76 Tex. 497 , I3 S. W. 542 (1890). But cf. Garrett v. Crawford, 128 Ga. 519, 57 S. E. 792 (1907); Bausman v. Eads, 46 Minn. 148,48 N. W. 769 (1891); Gunnell v. Cockerill, 84 Ill. 319 (1876); Hosmer v. Campbell, 98 Ill. 572 (1881).

${ }_{3} 3$ Jones, Mortanges (8th ed. I928) \$2034; Sielbeck v. Grothman, 248 1ll. 435, 94 N. E. 67 (1911); Lambert v. Livingston, 131 Ill. 161, 23 N. E. 352 (1890). In Sullivan v. Hardin, 102 S. W. (2d) 1110 (Tex. Civ. App. 1937), the court said: "Because sales by mortgagees and trustees under powers are more liable to abuse, they are more zealously watched by courts of equity, and upon slight proof of unfair conduct or violation of the powers given by the instrument, they will be set aside. While it is true that the presumption of regularity exists generally in favor of judicial sales, it is well-settled that no such presumption prevails as to trustee's sales under powers granted by deeds of trust, the reason for the rule being that the exercise of such powers is a harsh remedy and that it can only be exercised by strictly complying with the terms and conditions imposed upon the power of sale by the maker of the trust instrument."

${ }^{50} 3$ Jones, Mortgages $\$ 244 \mathrm{r}$. See, hovever, note 48 , supra.

v See Arnold v. Arnold, 325 Ill. 500, 156 N. E. 758 (1927).

${ }^{20}$ See Felker v. Southern Trust Co., 264 Fed. 798 (1920). In Illinois, under its recent Civil Practice Act, it appears that even independent adverse titles may now be adjudicated upon and settled in a fore. 
under a power all these are lacking. The deed conveys to the purchaser the mortgaged premises, subject to any prior encumbrances or liens. ${ }^{53}$ The question whether he does, in fact, take the premises subject to some other mortgage, lien, lease, or other interest is left to be subsequently-determined.

In weighing the merits of the two systems there is the additional element that the mortgagee possibly may be confronted with an action for damages at law by the mortgagor because of an alleged improper or wrongful exercise of a power of sale, ${ }^{54}$ whereas a foreclosure by suit in equity would not have subjected him to such a subsequent action.

\section{Proposed Act Based on Power of Sale Coupled with Novel Limitations as to Attack}

Every man's viewpoint as to the relative merits of these two general systems of foreclosing the mortgagor's equity of redemption is determined by his own experiences, training and background. The draftsmen of the proposed act clearly believe that the legislative policy of all of the states should be one of favoring the foreclosure of mortgages by extra-judicial exercise of a power of sale. ${ }^{55}$ While the act contains a proviso to the effect that any mortgage may be foreclosed by the mortgagee at his option by court action, ${ }^{56}$ the whole structure of the act is erected upon the foundation of a sale under a power to be contained in the mortgage. Consideration of this subject is complicated, however, by the fact that the power of sale provisions are closely interwoven with provisions which limit to a relatively few days the mortgagor's right to appeal to a court of equity for protection against an improper attempt to foreclose, but which do not assure that the mortgagor will hear about the contemplated sale in time to take any action for his protection. The act provides that the mortgagor shall have only the ninety-day period provided for the giving of notice within which to take such action. At the same time the act relieves the mortgagee from any consequences of failing to mail to the mortgagor notice of the proposed sale, thereby making it possible that during that period the mortgagor may not learn of the contemplated sale. It further limits an attack upon the sale itself to thirty days, again without any provision which will assure that the mortgagor will know of the sale within that time. Because of this fact, the operation of powers of sale in states where they commonly are used does not afford a true analogy to the method embodied in the proposed act. The combination of power of sale, strict and novel limitations upon the mortgagor's rights to challenge the mortgagee's procedure or the validity of the mortgage, and possibly lack of any knowledge reaching the mortgagor within the brief period when the courts would be open to him, will result in a procedure more closely approximating the establishment of a law day and forfeiture of the mortgagor's estate at common law than they do the sale under

\footnotetext{
closure suit. Trapp v. Gordon, 366 Ill. 102, 7 N. E. (2d) 869 (1937). And see Sielbeck v. Grothman, 248 Ill. 435,94 N. E. 67 (I9II).

${ }^{\infty}$ Proposed act, $\$ 37(\mathrm{c})$, appendix, infra.

${ }^{36}$ Burnett v. Dunn Commission \& Supply Co., 180 N. C. II7, 104 S. E. I37 (1920); Rogers v. Barnes, 169 Mass. 179, 47 N. E. 602 (1897); Federal Land Bank v. Robinson, I60 Miss. 546, 134 So. I 80 (I93I).

$\varpi \$_{30}$ et seq., appendix, infra. ts $\$ 2$.
} 
power in accordance with the laws of Massachusetts, Rhode Island or any of the other states which commonly use that method. In view of this there doubtless will be a sharp division of opinion as to the desirability of adopting as a uniform legislative policy sales under powers, coupled with provisions making the mortgagee's right to foreclosure reviewable by the courts only when the action is instituted before the sale occurs (and this without effective machinery to insure any knowledge of the threatened sale), as against equitable actions in which parties may present their contentions, have their rights adjudicated and their titles settled by courts of equity which are able to enforce contracts as well as to relieve against unconscionable actions or unduly harsh situations.

\section{Redemption Period}

To date the states have differed in determining the public policy to be followed in connection with allowing or not allowing mortgage debtors a period of time within which to redeem real estate sold at a mortgage foreclosure salc. Therefore it is to be expected that the fixing of a thirty-day redemption period will provoke much argument as among those who see no advantage in any redemption period and those who have the conviction that a reasonable redemption period is economically sound and socially desirable. From the mortgagee's viewpoint the absence of a redemption period, or the existence of a very short period for redemption, goes to the very heart of the problem of devising an effective foreclosure proceeding. From the viewpoint of the mortgagor an allowance of time for refinancing, or the lapse of a crop year, or some similar period before hope becomes dead, are matters of great importance. It will be argued on the one hand that the last few years have witnessed the greatest number of foreclosure suits in the country's history and that the percentage of redemptions has been so small that it has been demonstrated that redemption periods are of no use to mortgagors as a whole and are an unnecessary evil and uselessly expensive to mortgagees. And on the other side it will be contended that the severities of the immediate past are no true test; that the fundamental conception of a period for redemption is sound and that centuries of human experience ought not to be overlooked because of a temporary collapse of real estate values; that the desirability of a reasonable period within which mortgagors may financially rehabilitate themselves, or secure the loan of funds from other sources, or take advantage of rising realty values, or offset a poor crop with a subsequent good crop, outweighs the advantages flowing from quick foreclosures. It will also be argued that generally mortgagees are the purchasers at foreclosure sales because no one else bids and that the existence of a redemption right exerts a wholesome influence in causing bids to be made which approximate the value of the mortgaged premises. Certain it seems that no one provision of the proposed act will cause wider differences of opinion or more vigorous legislative battles. In states which always have adhered to substantial periods for redemption or which have adopted moratoria legislation the legislatures may well be adverse to the passage of an act which drastically shortens the existing statutory period. 
As against this, states which have experimented with the abolition of redemption periods and have been satisfied with the result are apt to be intolerant of other views. Securing substantial agreement on this subject may become the most difficult phase of securing uniformity in mortgage foreclosure law.

\section{Solution of Foreclosure Question Atrempted in Proposed Act}

The drafting of any act which is to have a reasonable chance of uniform adoption necessarily involves a balancing of the interests of the mortgagee on the ore hand, with those of the-mortgagor, on the other. Any undue advantage to one of these parties is obviously a corresponding detriment to the other. So in considering the prospective results and operation of the act if it were adopted, consideration must be given to its effect upon each. In this connection it must be remembered that the particular provisions under discussion are still in tentative form, and that in the evolution of the draft some changes may have been made or determined upon by the drafting committee, which have not yet been embodied in a published draft, but which make irrelevant parts of what follows. A discussion of parts of an act without setting forth the entire act and without quoting at length also is subject to the defect that it may not result in a fair or comprehensive view of the whole but in a picture distorted by disproportionate criticism of matters of relatively minor importance. However, the act is lengthy, and space is not available for setting it all forth in haec verba, even in a footnote. Therefore, there have been selected for discussion some of those provisions which will be most likely to result in differences of opinion as between mortgagor and mortgagee or to arouse legislative argument.

\section{From the Standpoint of the Mortgagee}

From the viewpoint of the mortgagee the act has two chief claims to merit: it should furnish a speedy and inexpensive remedy; and if uniformly adopted, lenders of money who do a country-wide business would find their foreclosure problems simplified and relieved of the great confusion which now exists when foreclosures are necessary in many states.

The act provides simple and short procedure. It contemplates a foreclosure proceeding entirely within the control of the mortgagee, without any recourse to the courts, to be completed in one hundred and twenty days, ninety days being allowed for notice and thirty days additional before the purchaser acquires title. The notice provided for consists of a specified form to be recorded at least ninety days before sale, to be published three times during the ninety days, and to be mailed at least sixty days prior to the sale to each person "actually known" to the mortgagee to have an interest in the mortgaged premises. ${ }^{57}$ At the appointed time the sheriff of the county in which the mortgaged premises are located is required to sell at public auction to the highest bidder. ${ }^{58}$ Thereafter only thirty days are allowed for redemption by the mortgagor, junior lienors having no right to redeem. At the end of the thirty days a deed issues and the foreclosure is complete. Speed is further assured

\footnotetext{
$\sigma_{\$ 3}(\mathrm{a})$, appendix, infra.

$\approx \$ 33(a)$, appendix, infra.
} 
by closely restricting the mortgagor's remedy to attack the foreclosure proceedings $5^{50}$ or to take action to have the sale set aside. ${ }^{60}$ Few states offer a more expeditious method though some do not require as much as ninety days' notice or allow any redemption. On the whole the act should appeal strongly to mortgagees.

However, even the viewpoint of the mortgagee speed and cheapness are only two elements to be considered. A third element has to do with the title flowing out of the foreclosure. Apparently with this element in mind there has been provided an optional court procedure for confirmation of the foreclosure sale. ${ }^{i 1}$ This raises the query: If a court procedure is necessary or desirable to confirm the sale and to settle the title, what has been gained over a court action to foreclose? The answer may be that in the great majority of instances it would be unnecessary to resort to such an action but that in those instances where it may appear to be desirable the remedy has been provided.

Viewed as a whole, the act provides the mortgagee with a remedy designed to permit him to acquire the mortgaged premises in the event of a default with little motion, in a short time, at trifling expense, free from subsequent attack. This very circumstance might, however, furnish an incentive to a mortgagor having no other remedy to institute a counter offensive by way of a suit at law for damages against the mortgagee for alleged irregular or wrongful extra-judicial foreclosure. ${ }^{62}$ A jury in such a suit might be inclined to give the plaintiff-mortgagor the benefit of any doubt in connection with controverted issues of fact. It is true that Section $3^{\mathrm{I}}$ of the act relieves the mortgagee from an action for damages for failure to mail notice of the foreclosure sale to each person actually known to him to have an interest in the real estate covered by the mortgage. But this is the only exemption from such action provided for. There might be omissions by a mortgagee to comply with other provisions of the proposed act, and a number of different combinations of circumstances might arise which would afford an opportunity for a mortgagor, whose property had quickly been lost beyond recall as a result of the extra-judicial foreclosure sale, to commence an action at law against the mortgagee for damages. Any advantages of speed and economy might be lost to a mortgagee who found himself forced to defend such an action.

\section{From the Standpoint of the Mortgagor}

One of the provisions likely to appeal to mortgagors is designed to prevent unconscionable deficiency judgments against mortgagors and to compel mortgagees to credit mortgagors with the value of the premises acquired through foreclosure. ${ }^{\text {i3 }}$ During recent years many bills have been introduced in state legislatures seeking this end, for the flood of mortgage foreclosures disclosed many situations where mortgagors lost their properties at prices far below values and then found themselves

$\$ \$ 32,34(\mathrm{~b})(\mathrm{c})$, appendix, infra.

61 $\$ 35$, appendix, infra.

${ }^{\infty} \$ 34$, appendix, infra.

${ }^{22}$ See note 54 , supra.

As to the validity of such provisions under the Pennsylvania constitution, see Pennsylvania Co. for Insurances, etc. v. Scott, $329 \mathrm{~Pa}$. 534, $198 \mathrm{Atl}$. I15 (2938). 
subject to judgments for large portions of the mortgage debt. ${ }^{64}$ To meet this situation Section $3^{6}$ of the proposed act limits the mortgagee's right to a deficiency judgment after sale. The amount of a judgment which may then be recovered is not governed by the difference between the mortgage debt and the sale price of the property, but by the difference between the mortgage debt, plus statutory costs and expenses, and the fair market value of the property at the time of the foreclosure sale. However, other sections seem to offer a method by which the mortgagee may escape the effect of the provisions of Section 36 . He may first sue at law and obtain a judgment against the party personally liable on the mortgage debt and have an execution issued. If the execution is returned unsatisfied in whole or in part, the mortgagee may then foreclose by exercise of the power of sale. ${ }^{65}$ Under such circumstances the mortgagee would have had his judgment at the outset, the amount of his bid would not be affected thereby, and it would be unnecessary for him to proceed after sale for a deficiency under the provisions of Section $3^{6}$.

It may also be noted that it is possible for a mortgagee to obtain an allowance for attorney's fees as a part of the costs in an action for a deficiency under Section 36, or by application for a deficiency judgment in connection with a proceedings to confirm the foreclosure sale under Section $35{ }^{66}$

\section{Limitations upon Mortgagors' Access to Courts of Equity}

From the viewpoint of the mortgagor, one important feature of the proposed act is the limitation which it fixes upon the time within which he may resort to a court to protect his rights or assert his contentions. In order to obtain a judicial determination concerning matters which warrant the court in enjoining a foreclosure sale in the first instance, and these would appear to include such vital questions as the validity or existence of the mortgage foreclosed, the existence of a breach warranting foreclosure, any matters which would preclude foreclosure, or sufficiency of the notice of sale, he must file his action prior to the date of sale fixed in the mortgagee's statutory notice. $^{\mathbf{6 7}}$ After that date all such matters are barred, even in an action to set aside the sale, for in an action to rescind, the mortgagor may draw in question only irregularities occurring at the sale. He is not entitled to any relief which he might have obtained by a petition for injunction prior to sale. The purpose of these

\footnotetext{
(4) Sec e.g., Ariz. Rev. Code (Courtright, Supp. 1936) \$2324; Idaho Laws 1937, c. 3I, p. 42; N. J. Rev. Stat. (1937) 2:65-2 et seq.; N. X. Civ. PrAc. Act (Cahill, 1937) §ro83a; N. C. Code (Michie, 1935) $\$ \$ 2593(\mathrm{~b}-\mathrm{d})$. From 1917 to 1921 the Illinois law provided for the issuance of a certificate of indebtedness upon the entry of a foreclosure decree and the passage of the statutory period for redemption beforc the foreclosure sale occurred. Largely because of the small bids made, and the corresponding large deficiencies when sales occurred from which no redemption was possible, the act was repealed after a short trial and the former practice reestablished of holding sales shortly after decrec, having the court confirm or disaffirm the sale, and providing for redemption from the sale, not from the mortgage debt. ILL. REv. Stat. (1937) c. 77, 516 et seq.

\% 530 , appendix, infra.

${ }^{60} \$_{3} 8$ (last sentence), appendix, infra.

or It would seem, in fact, that this petition must be filed more than ten days prior to the date fixed for sale, since its prayer is for an order requiring the mortgagee to show cause within ten days from date of the order why the sale shall not be enjoined, and the return date of the order to show cause must be a date prior to the date of the foreclosure sale.
} 
provisions appears to be to compel the mortgagor, who desires to institute court action, to proceed promptly, but are they so effective for the mortgagee as to be unduly harsh on the mortgagor?

In order to test the practical operation of these provisions assume the existence of a small principal balance on a mortgage which has been four-fifths paid, upon which by the terms of the documents neither principal nor interest is in default, nor any other breach exists, and with the mortgagor in the occupancy of the mortgaged premises. Although no payment is in default, the mortgagee prepares, records and publishes a statutory notice of foreclosure sale in accordance with Section 3 I of the proposed act, omitting, however, to mail notice of the sale to the mortgagor, who has no knowledge of the foreclosure proceedings thus set in motion. Unknown to the mortgagor the sale is held on the date fixed and the property sold. No further action is taken until thirty days after the sale has expired when the purchaser obtains and records a certificate of sale, or deed. Seven days later the purchaser obtains an ex parte order under Section 37 (d) for possession and the mortgagor first learns of the proceedings when the sheriff appears with a writ of assistance and evicts him.

Although no default under the mortgage existed and although the mortgage debt had been four-fifths paid and the balance was not due, under the language of the act the mortgagor would have no remedy. If all of the provisions of the act are valid he would be in a difficult position. The ninety-day period for notice having expired he could not thereafter question the right of the mortgagee to foreclose. The thirtyday period for redemption having expired he could no longer redeem. And even though the whole unfortunate affair was due to the mortgagee's plain failure to mail him notice the mortgagor would still be without a remedy under the act, for while the act provides for the mailing of notice to all persons actually known to have an interest in the mortgaged premises a proviso to Section $3^{\mathrm{r}}$ negatives the effectiveness of the provision by providing that "failure to mail such notice shall not invalidate the foreclosure nor be grounds for any action in damages." Even had he learned of the sale within thirty days after it occurred and within that time com. menced an action to rescind under Section 34, yet he could not in such action to rescind have raised any question concerning either failure to mail notice, or the existence of a breach of his covenant to pay, because those were questions which he might have raised by a petition to enjoin before the sale ${ }^{68}$ and the action to rescind does not afford to the mortgagor any relief which was available to him "prior to the foreclosure sale."69

The illustration given may be varied, it seems, with the same unfortunate result to the mortgagor. He may never have executed the alleged mortgage, or his real estate may not have been, in fact, subject to it. ${ }^{70}$ Yet it seems that a mortgagor who remains in ignorance of the proceedings until after the deed issues, though guilty of

\footnotetext{
${ }^{e} \$_{32}$, appendix, infra. $\quad{ }^{\infty} \$_{34}(c)$, appendix, infra.
}

${ }^{70}$ Relief on such grounds, it seems, would clearly have been dvailable to the mortgagor prior to the foreclosure sale. $\$ 34(\mathrm{~b})(\mathrm{c})$, appendix, infra. 
no fault of his own, would be barred, under the provisions of the proposed act, from applying to a court for a restoration of his property.

\section{Notice to Mortgagor of Foreclosure Sale}

The question of notice is particularly troublesome. ${ }^{11}$ Possibilities as to provisions for notice vary from no requirement of notice to the personal service of notice on all parties interested some period in advance of the sale. Other alternatives are the California plan of permitting the parties entitled to notice to record the address to which they desire notice sent and requiring notice to be mailed to all such addresses, ${ }^{72}$ or the plan of requiring a short notice if the mortgagor is personally served, a much longer period to elapse if he is not served, thereby decreasing the possibilities of a foreclosure sale without his knowledge.

If notice is not mailed, the mortgagor must acquire notice of the proceedings, if at all, either through (I) the notice which the mortgagee is required to record, or (2) the publication which the mortgagee is required to make in a newspaper of general circulation published in the county where the real estate is situated. ${ }^{\mathbf{3}}$ It is not at all unlikely, especially in the larger cities, that neither of these notices would actually come to the attention of the mortgagor during the short period within which he is permitted, under the proposed act, to apply to the court for relief.

However, the problem here presented cannot be solved merely by answering the general question of whether it is necessary or desirable that the mortgagor be given actual notice in case of foreclosure by power of sale. Under the proposed act the question of notice is so intimately tied up with the short time limitation placed upon the mortgagor's right to apply to a court for a determination of his rights, that the real inquiry is whether the proposed act provides a method of procedure by which the mortgagor's property may be summarily taken from him by extra-judicial proceedings without any reasonable likelihood that the mortgagor will, as a practical matter, have an opportunity to obtain any judicial hearing either before or after the event. The ordinary question of notice to the mortgagor in cases of foreclosure by power of sale does not present the same difficulty. The accompanying limitation period within which the mortgagor may seek relief, if there is such a limitation - statute, ordinarily is long enough to give the mortgagor a reasonable opportunity to learn what has happened and apply for judicial relief ${ }^{74}$ and courts of:equity usually have been liberal in awarding the mortgagor relief against wrongful or improper exercise of the power of sale. ${ }^{75}$ Under circumstances where want of notice to the mortgagor of the foreclosure sale cannot reasonably operate to bar him, as a practical

\footnotetext{
II In a note appended to $\$ 16 \mathrm{~A}$ of the 1927 proposed act, dealing with notice of the foreclosure sale under power contained in the mortgage, the Commissioners say: "This section has caused more difficulty than any other, and in each draft it has been changed." Draft of Uniform Act of r927, p. 33 .

172 Cal. Civ. Code, $\$ 2924$ b (Cal. Stat. I933, p. I670).

731 , appendix, infra.

${ }^{\pi} \mathrm{Sec}$, in general: 3 Jones, Mortanges $\$ 2330$ et seq., \$245I et seq.; $4 \mathrm{I}$ C. J. 1024 et seq. In 3 Jones, Mortgnges $\$ 2330$, the general rule is stated: "If in any case it is attempted to pervert the power from its legitimate purpose, and to use it for the purpose of oppressing the debtor, or of enabling the creditor to acquire the property himself, a court of equity will enjoin the sale, or will set it aside after it is made."
} 
matter, from applying for judicial relief, the matter of notice is not so material. In fact there may be considerations why a statute providing for foreclosure by power of sale need not make the giving of personal notice to the mortgagor mandatory, ${ }^{76}$ at least as to properties other than homesteads or possibly agricultural properties. Under a statute making notice mandatory failure to give notice might be held to void the sale ${ }^{77}$ and since the question of whether such notice had or had not been given in any particular case would necessarily be a matter resting in parol, not determinable from the public records, the result would be that titles coming through such foreclosure sales conducted under such a statute might be clouded and rendered uncertain. ${ }^{78}$ But where, as under the proposed act, provisions making actual notice to the mortgagor unnecessary are interwoven with other provisions which fix so short a time limit upon the mortgagee's right to apply to the courts for relief that want of, notice is, as a matter of practical effect, equivalent to no right to a judicial hearing, then a different situation is presented.

The features of the proposed act just mentioned would seem to be sufficient to raise a question as to the act's constitutionality. ${ }^{79}$ But regardless of questions of constitutionality, mortgagors may well urge that the provisions limiting to such a short period their right to apply to the courts for relief, when considered in connection with the absence of any requirements reasonably calculated to afford them any actual notice within the time in which they are compelled to apply for relief, renders the proposed act harsh and oppressive.

\section{Actions to Enjoin or Rescind the Foreclosure Sale}

Even where a mortgagor learns of contemplated improper foreclosure proceedings before it is too late to file a petition under Section 32 to enjoin the foreclosure sale,

${ }^{70}$ Draft of Uniform Act of 1927 , note to $\$ 16 \mathrm{~A}, \mathrm{p} .33$.

${ }^{7}$ Hunt v. Boyce, 176 Ark. 303,3 S. W. (2d) 3342 (1928).

${ }^{7}$ A statute which does not require such notice is not, for that reason alone, in violation of the due process and equal protection clauses of the Fourteenth Amendment to the Federal Constitution. Scott v. Paisley, 271 U. S. 632 (1926). This case does not, however, consider the effect of such a provision coupled with a time limitation upon the right of the mortgagor to be heard of the character found in the proposed act.

"In 2 Cooley, Constitutionaz Limirations (8th ed. x927) 763,764 , it is said: "It has consequently been held that a statute which, after a lapse of five years, makes a recorded deed purporting to be executed under a statutory power conclusive evidence of a good title, could not be valid as a limitation law against the original owner in possession of the land. Limitation laws cannot compel a resort to legal proceedings by one who is already in the complete enjoyment of all he claims." See Groesbeck v. Secley, 13 Mich. 329 (1865); Martin v. White, 53 Ore. 319, 100 Pac. 290 (1909); People v. Simon, 176 Ill. 165, 52 N. E. 910,915 ( 1898$)$; Gilman v. Tucker, 128 N. Y. 190,28 N. E. 1040 (1891). But cf. Fitger v. Alger, Smith \& Co., 130 Minn. 520, 153 N. W. 997 (1915); Leffingwell v. Warren, 67 U. S. 599 (1862); American Land Co. v. Zeiss, 219 U. S. 47 (I9II). Some state constitutions preclude the legislature from depriving courts of equity of any part of their jurisdiction. Howell v. Moores, 127 Ill. 67 , I9 N. E. 863 (1889); Stephens v. C. B. \& Q. R. R., 303 Ill. 49, I35 N. E. 68 (1922); German Nat. Bank v. Moore, 116 Ark. 490 , $173 \mathrm{~S}$. W. 401 (1915). It may be said, however, that the proposed act does not purport to deprive courts of equity of jurisdiction, but rather to limit the time within which application must be made for relicf. $\Lambda$ limitation statute, however, is void if the period allowed is unreasonably short. Lamb v Powder River Live Stock Co., 132 Fed. 434 (1904). And see Bell v. Union Planters Bank \& Trust Co., I58 Miss. 486 , 130 So. 486 (1930); I2 C. J. 978 , 979. With reference to a further constitutional question relating to amendment of other separate statutes concerning practice and limitations, compare Brooks $v$. Hatch, 261 Ill. 179, 103 N. E. 745 (1913), with State v. Milauskas, 318 1ll. 198, 149 N. E. 294 (1925). 
or to commence action under Section 34 to rescind, the proposed act contains some provisions which may deter, or even effectively preclude him from seeking a judicial determination of his rights in connection with the mortgage, or foreclosure sale.

For one thing, the mortgagor must face the contingency of paying the mortgagee's attorney's fees if he is unsuccessful in an action to enjoin under Section 32. If the judicial hearing were contested and long drawn out, as might well be the case, especially if there were an appeal, the attorney's fees which the mortgagor would be compelled to pay, if ultimately he should be unsuccessful, would amount to a considerable sum.

Another provision requires the mortgagor to advance a certain sum in cash, or in any event a bond, as a condition to his right to a judicial hearing. Section 32 requires the mortgagor, as a condition precedent, to pay into court the sum of $\$ 250$, or a sum equal to one-tenth of the unpaid balance of the obligation "set forth in the statutory notice of foreclosure sale," whichever is less, or to furnish a bond in like amount satisfactory to the court. If the mortgagor is unsuccessful, such sum so to be paid into court or secured by bond, is to be paid to the mortgagee and applied by the mortgagee on account of his costs and his attorney's fees, and the balance is to be applied in reduction of the unpaid amount of the obligation. Section 32 , it is true, provides that the court "may approve a smaller sum, or bond." The obvious purpose, however, of the act is to indemnify the mortgagee against any loss by reason of costs and attorney's fees if the mortgagor is unsuccessful in the litigation. Litigation of this character, especially in urban areas, would not need to be extended to any great length in order for the mortgagee to incur attorney's fees to the extent of $\$ 250$. Consequently the court could not, unless it were to ignore the avowed purpose of the act, give the mortgagor much relief by way of reducing the amount to be deposited or the amount of the bond. A small home owner might find it impossible on short notice to raise the cash which he would be required to advance as a condition precedent to his right to be heard. And so far as the bond is concerned, a mortgagor who could not raise the cash required obviously would have great diffculty in finding any responsibile surety who would execute a bond obligating him to pay the mortgagee's attorney's fees in what might well be extensive litigation.

A mortgagor who institutes an action to rescind the foreclosure sale may thereby waive any right to redeem within the thirty-day period. Under Section 34(a), it is provided that in the mortgagor's action to rescind the provisions of the laws of the State "with respect to the commencing of proceedings in equity shall be complied with." This would mean the filing of a formal bill or complaint and the service of process. It is highly unlikely that such a proceeding could be brought to a final determination within the short period of thirty days, regardless of how diligently prosecuted. If the suit was not terminated within that period and the court's decision were adverse to the mortgagor the period within which he might have redeemed would have expired. Section 35 (e) of the proposed act unconditionally requires a mortgagor to redeem within thirty days, if he is to exercise that right. The practical 
effect would be to compel a mortgagor to choose between the right to redeem and an action to rescind.

The thirty-day period after sale allowed the mortgagor to redeem may deter a mortgagor from defending a petition by the mortgagee or purchaser to confirm a foreclosure sale under Section 35. This section also requires compliance with usual chancery procedure when the mortgagee or purchaser brings an action to confirm. Again there is little likelihood that such a proceeding could be brought to a final conclusion within thirty days after sale. So here also the mortgagor has to choose between defending such an action or redeeming within the thirty days, thereby waiving any defense which he might have.

\section{Redemption}

Section $35(\mathrm{e})$ requires the mortgagor who redeems to tender to the sheriff, within thirty days after the foreclosure sale, not the foreclosure sale price, but "a sum equivalent to the unpaid balance of the obligation plus all costs and expenses," and a small sheriff's fee for executing a certificate of redemption. In effect this is a provision for redeeming from the debt even after sale, instead of redeeming from the sale. It would seem to be a reversal of the generally existing policy of encouraging redemptions. For one thing, if mortgaged premises worth less than the mortgage debt were sold to the mortgagee even for their then full market value the mortgagor and those claiming under him could not redeem by paying the full value of the property, but only by paying the full mortgage debt and attendant costs. For another, if a stranger became the purchaser at a price less than the mortgage debt, neither the mortgagor nor anyone claiming under him could redeem without paying both the sale price and the deficiency remaining due to the mortgagee.

The disposition to be made by the sheriff of such redemption money is not clearly covered by any express provision of the act. Presumably the intention is that the sheriff should hold moneys paid at the foreclosure sale until the redemption period has expired, and if redemption is made account to the purchaser in connection with moneys which had been paid at the sale and dispose of the redemption money on the theory that it was paid for the benefit of the mortgagee.

\section{The Position of Parties with Subordinate Interests}

One interesting aspect of the act is that a junior mortgagee or lienor has no right to redeem. ${ }^{80}$

Disputes may arise between the mortgagee and third parties having an interest in the premises subordinate to the mortgage as to the amount due, the validity of the lien of the mortgage being foreclosed, and like matters. Section 32, relating to the enjoining of the foreclosure sale, requires the deposit of cash or a bond, the amount of which may be applied on costs, attorney's fees, and in reduction of the mortgage

${ }^{50} \$ 35(\mathrm{c})$, appendix, infra. Under Article I of the proposed act, a "mortgagor" is defined to mean the person who has executed a mortgage or whose interest in the mortgaged premises is subject to the mortgage "excluding junior nortgagees and lienors." 
debt, if the petitioner is unsuccessful. Section 34 (c) provides that the remedy of injunction provided in Section 32 "is the only remedy by which a mortgagor may prevent a foreclosure sale." However, junior mortgagees and lienors are not included within the definition of morigagor. Therefore equity might very well hold that the act did not expressly deny it the right to permit junior mortgagees and lienors to proceed to enjoin the sale by ordinary suit in equity, and that they might proceed to enjoin a sale either (I) by ordinary suit or (2) by proceeding under Section 32, at their election. But other third parties, except junior mortgagees or lienors who are excluded from the definition of "mortgagor," would seem to be precluded from asserting this position because they fall within the express provisions of Section 34(c). It is difficult to see why a third party-as, for example, a lessee-who is not liable for payment of the mortgage debt but whose rights might be adversely affected by a foreclosure, should be required to pay the moneys, or furnish the bond required under Section 32, as a condition precedent to his right to be heard as to the existence of the alleged mortgage, whether it has been validly executed, whether it takes precedence over his rights, or whether the real estate is subject to such an alleged mortgage. Yet under the language of the proposed act it seems that the only third parties who might rely upon the ground above mentioned to claim immunity from the provisions of Section 32 would be junior mortgagees or lienors.

Section 34 (b), however, is more comprehensive. It provides that unless an action to rescind under the act shall have been commenced within thirty days after the date of the foreclosure sale "no action or proceeding at law or in equity shall be begun by any person in any court of this State to rescind or set aside a foreclosure sale conducted under the provisions of this article or to rescind, set aside or modify any certificate of such foreclosure sale." All parties, including junior mortgagees and lienors, are included within the language of Section 34(b). Consequently, a junior mortgagee or lienor who-remained in ignorance of the foreclosure sale for thirty days after it had been held, would be in the same predicament as a mortgagor who suffered a like misfortune. It seems that under the proposed act the right to their day in court would be gone.

If a mortgagee or purchaser takes affirmative action under Section 35 to have a sale confirmed, and persons with interests subordinate- to the mortgage foreclosed are made parties defendant, it appears that the court is authorized to charge such defendants with the mortgagee's or purchaser's attorney's fees, if he is successful. ${ }^{81}$ And if any party with an interest subordinate to the mortgage being foreclosed seeks to defend by petition to enjoin under Section 32, or by action to rescind under Section 34, he may, if unsuccessful, be compelled to pay the mortgagee's attorney's fees.

The provisions of the proposed act will probably have the practical effect of discouraging, to some extent, junior mortgage financing.

at $\S_{3} 8$ (b) (last sentence), appendix, infra. 


\section{Statutory Form of Mortgage}

The act provides a short statutory form of mortgage containing twelve covenants of the mortgagor, each expressed in a few words. Thereafter, various phrases embodied in the form of mortgage are given extended meanings. The principal object is to lessen recording expense. While the object sought to be attained is desirable, yet the provisions may prove to be a subject productive of controversy. The device of giving a statutory construction to words used in instruments of conveyance is not new and frequently is to be found. ${ }^{82}$ But from the viewpoint of the mortgagor it may be urged that the short form under consideration is subject to the criticism that the extended meanings are not indicated by or apparent from the words actually used. There has always been considerable prejudice against the use of "fine print" in contracts, and the same principle underlying that objection might here lead to strong opposition on the ground that even the closest examination of the short form itself would not reflect the actual burdens imposed by the extended meanings. The statutory meanings given by the proposed act to the various clauses of the statutory form are long and very comprehensive. Thus the covenant of the mortgagor "to pay all taxes" is given an extended meaning which is elaborated into twenty-two lines of printed matter. Likewise, the obligation to insure is enlarged into five lengthy paragraphs. "The mortgagor hereby mortgages to the mortgagee" is elaborated to mean "that the mortgagor, for valid consideration, grants, bargains, sells, releases and conveys" the mortgaged premises, "including all homestead and dower rights." Most state statutes already construe the effect of using "grant, bargain and sell" in a conveyance, and have specific and sometimes rigid provisions relative to the conveyance or waiver of homestead or dower rights, so that in many states questions of repeal of existing statutory provisions by implication would be present were the act to be adopted in its present form. But those are matters of the legislative draftmanship which can be solved. It seems that ground for possible opposition might be minimized by making the statutory meanings less comprehensive or by expanding the provisions of the statutory form if necessary to afford a more complete index to the statutory meanings given the various clauses.

The act also gives the extended meanings to the words set forth, whether they are used in the statutory short form of mortgage, or in any other mortgage. The wisdom of this also may be the subject of debate. Parties might, without any intention or wish to adopt the statutory mortgage and the meanings set forth in the act, happen to use the common clauses mentioned or words of equivalent import, and the effect would seem to be to give their mortgage, under those circumstances, a meaning which it was not supposed nor intended that it should have. It would seem that such a result could be prevented by modifying the proposed act to confine the expanded meanings to the statutory form of mortgage and by incorporating in such form a further proviso that when used they should have the statutory meanings set forth in the act.

${ }^{80}$ See, e.g., Irl. Ruzv. Stat. (1937) c. 30, \$\$7-10. 


\section{The SCOpe of a UNIform Law}

In addition to the matters above presented the act contains a large amount of detail as to procedure and as to forms and the precise words to be used in filling them out. It covers practically every minute item from the drafting of a mortgage to the last act to be performed in connection with its release or foreclosure. This method of draftsmanship may be subject to two criticisms: one that it imposes risks attendant upon variations from the precise words and directions of the act, and the other that uniform legislation should not attempt to deal too much with details of procedure. General common law rules governing mortgages and foreclosures, and this includes foreclosures by power of sale as well as by suit, have been worked out and generally established in the United States through more than a century of court decisions. ${ }^{83}$ These precedents are so numerous as to furnish a fairly reliable guide as to matters of procedure, and they leave the law flexible enough to allow some "play in the joints" to cover any unusual state of facts which may arise. It is difficult for the human mind to foresee all these contingencies. To attempt to do so and to codify the rules of procedure in minute detail may require the courts to commence on a new course of construction and interpretation of the code provided. Meanwhile litigants and lawyers remain in uncertainty. Legislatures must correct mistakes and inconsistencies which actual cases can, and likely will, disclose.

Where many subjects are combined in one act there always is danger that opposition to parts may cause rejection of the whole. The main features of the act are two -destruction of long redemption periods and the simplification of foreclosures. Elimination of either feature may defeat the whole purpose of the act, but it has been suggested in the National Conference of Commissioners on Uniform State Laws that possibly greater progress in foreclosure procedure could be obtained through a series of acts, one providing a statutory form of mortgage and its construction, and others seeking to improve the existing foreclosure mechanisms, legalizing sales under powers, revising redemption laws and fixing limitation periods for attacking foreclosure sales.

The difficulties of the problem cannot be minimized nor can the solution be found overnight. The work of the drafting committee to date has stimulated thought and provoked discussion throughout the country. The studies made, the data compiled, and the light shed by a nation-wide survey of the facts, are of inestimable value. The proposed act is still in a formative state, and only the most searching and critical examination can provoke the type of discussion and exchange of ideas necessary to bring forth the best possible final result. Out of the ensuing serious consideration the answer to a most difficult problem should appear, for it is apparent that some states have experienced reasonably satisfactory results in their mortgage foreclosure problems and others obviously unsatisfactory results. To the tireless work and enthusiasm of the members of the group which has undertaken leadership in seeking a solution the bar in particular, and the country in general, are indebted.

${ }^{80}{ }_{41}$ C. J. 922 et seq. 
Their task is a difficult one, but they have behind their efforts the cooperation and constructive help of all who seek improvements in foreclosure procedure.

\section{APPENDIX}

An important subdivision of the proposed act is Article IV, relating to foreclosure. The following are the principal provisions of this article as they appear in latest draft of the proposed act, obtained from the Sub-Committee on Law and Legislation of the Central Housing Committee in October, 1938.

`30. RIGHT OF SALE. A mortgagee may foreclose a recorded mortgage, provided all assignments thereof have been recorded, by exercising the statutory right of sale in accordance with the provisions of this article. Such statutory right of sale is irrevocable and shall not be suspended or terminated by death or incapacity. When a mortgage creates a power of sale or a right of sale or when a mortgage provides that it shall be enforced in accordance with the provisions of this act or when the partics to a mortgage have agreed in a recorded writing that such mortgage shall be enforced in accordance with the provisions of this act, a mortgagee may exercise the statutory right of sale prescribed by this act; provided, that any cuvenant of the mortgage has been breached and that no action or proceeding is pending at law or in cquity to recover any part of the obligation secured by the mortgage; or provided, that an execution upon a judgment for any part. of the unpaid balance of an obligation secured by the mortgage has been returncd unsatisficd in whole or in part. Any attempted exercise of the right of salc shall not cxhaust the right of sale until the title to the property described in the mortgage has effectively passed as a result of such foreclosure sale.

\$31. Statutory Notice of Foreclosure Sal.. a. In order to foreclose a mortgage under the pro. visions of this act, the following form of statutory notice of foreclosure sale shall (1) be recorded in each county in which the rea! estate covered by the mortgage to be foreclosed is situated at least 90 days prior to the date of the foreclosure sale fixed in the notice of foreclosure sale, (2) be published once a week for 3 successive weeks, prior to the foreclosure sale, the first publication to be not more than 30 days prior to the date of the foreclosure sale in a newspaper printed in the English language of general circulation and published in the county in which the real estate covered by the mortgage is situated (and if the real estate is situated in more than one county, in each of the counties in which the real estate is situated) and if no such newspaper is published in any such county, the publication shall be in a newspaper or news. papers printed in the English language of general circulation in each of such countics, and (3) not less than 60 days prior to the date of the foreclosure sale, be mailed to each person actually known to the mortgagee to have an interest in the real estate covered by the mortgage; provided, that failure to mail such notice shall not invalidate the foreclosure nor be grounds for any action in damage: [Here follow the statutory form of notice of foreclosure sale, and subscetions $b$ and $c$, rclating to adjournment of the foreclosure sale and cancellation of notice of such sale by the mortgagec.]

332. EnJoIninc Foreclosure SALE. After the statutory notice of foreclosure sale prescribed in this article shall have been recorded and filed, as required by this article, and before the date of the forcelosure sale, any person having an interest in the real estate covcred by the mortgage being forcelosed or obligated upon the obligation secured by the mortgage may file a verified petition in any court for the county in which the foreclosure sale is noticed to be held, in term or in vacation, for an order requiring the mortgagee to show cause within 10 days from the date of said order why the foreclosure sale shall not b: enjoined; provided, however, the return date of said order to show cause shall be a date prior to the date of the foreclosure salc. In the event that the court issues such order to show cause, the same shall operate as a temporary order restraining the mortgagee and all other persons from conducting the foreclosure sale until the court shall either enjoin such foreclosure sale or dissolve such order to show cause in accordance with the merits of the case. The petition shall set forth facts sufficient to support an injunction.

The petitioner shall aiso pay into court the sum of $\$ 250$ or a sum equivalent to one-tenth of the unpaid balance of the obligation set forth in the statutory notice of foreclosure sale, whichever is less, or furnish a bond in like amount, satisfactory to the court, to be held by the court pending the termination of the cause. The court may approve a smaller sum or bond to be deposited. On the return day of said order to show cause, the court, in term or in vacation, shall hear the interested parties and shall determine all of the rights of the parties in accordance with the merits of the case, and either enjoin the foreclosure sale, or dissolve the order to show cause and make such other and further orders as seem just and equitable. In the event the court shall dissolve the order to show cause, the petitioner shall pay the costs, as de. termined by the court. including reasonable attorneys' fees, and the surn paid by the petitioner into court 
or secured by petitioner's bond shall be paid to the mortgagee and shall be applied by the mortgagee on account of the costs and attorneys' fees, and the balance in reduction of the unpaid balance of the obligation. In the cvent the court shall enjoin the foreclosure sale, the mortgagee shall pay the costs, and, after final determination of the cause, any sum paid into court by the petitioner shall be refunded to the peti- tioner and any bond given by such petitioner shall become void and shall be returned to the petitioner. In' the event the court shall dissolve the order to show cause, the order dissolving the same shall designate the day and time of day at which the foreclosure sale shall be held, which day shall be the day fixed in the notice of foreclosure sale or within ro days after the date of such order, whichever is later.

\$33. Foreclosure Sale. a. Provided foreclosure sale shall not have been enjoined, the sheriff of the county in which the sale is to be held, at the place and the time of day and on the date fixed by the notice of forcelosure sale or by a coure order in accordance with this article, shall sell at public auction to the highest bidder the mortgaged premises described in the notice of such foreclosure sale. Any person having any interest in the mortgaged premises or in the obligation secured by the mortgage, including the mortgagor and the mortgagee, may bid for and purchase all or any part of the mortgaged premises at the foreclosure sale. ... [Here follow subsections $b$ and $c$, relating to conduct of sale.] ... After the foreclosure sale has become final in accordance with the provisions of this article, such proceeds of the sale shall be applied, first, to the payment of statutory costs and expenses, second, to the satisfaction of the unpaid balance of the obligation secured by the mortgage foreclosed, and the balance, if there be any surplus, shall be paid after 30 days from the date of the foreclosure sale into court for distribution to the original mortgagor, his successor in title, or other persons who may be entitled thereto.

\$34. Action to Rescind Foreclosure Sale. a. Within (but in no event later than) 30 days after the date of a foreclosure sale conducted under the provisions of this article, an action to rescind such foreclosure sale may be commenced by petition to any court for the county where such foreclosure sale was held by any person having an interest in the foreclosed real estate or who is obligated under the obligation securing the foreclosed mortgage. The provisions of the law of this State with respect to the commencing of proceedings in equity shall be complied with. Such petition shall allege each specific violation of this act which the petitioner deems to have occurred at the foreclosure sale. If the court, in term or in vacation, shall find that the provisions of section 33 of this act have not been complied with or that the sale was otherwise irregular, the court, in term or in vacation, as expeditiously as the ends of justice permit, shall enter a final order rescinding the foreclosure sale. If the court shall find that such provisions have been complied with and that the foreclosure sale was regular in all respects, the court, in term or in vacation, as expeditiously as the ends of justice permit, shall enter a final order confirming the foreclosure sale. An order rescinding a forcclosure sale may be recorded by the mortgagor in each place where the foreclosed mortgage was recorded. Upon the entry by the court of such order rescinding the foreclosure sale, the mortgage shall be revived as though no notice of forcclosure sale had been given and no foreclosure sale conducted; but no such order shall prevent the mortgagee thereafter from again exercising the right of sale in accordance with the provisions of this article.

b. Unless an action to rescind a foreclosure salc conducted under the provisions of this article shall have been commenced within 30 days after the date of the foreclosure sale, no action or proceeding at law or in equity shall be begun by any person in any court of this State to rescind or set aside a foreclosure sale conducted under the provisions of this article or to rescind, set aside or modify any certificate of such foreclosurc salc.

c. The remedy of injunction provided in section 32 of this aft is the only remedy by which a mortgagor may prevent a forcelosure sale from being conducted under the provisions of this act. The action to rescind a foreclosure salc shall not afford to the mortgagor any relief which was available to the mortgagor prior to the foreclosure sale. Such action to rescind shall be limited by the courts of this State to violations of law in connection with the foreclosure sale.

\$35. Petition for Confirmation of Foreclosure Sale. a. Within (but in no event later than) 30 days after a foreclosure sale conducted under the provisions of this article, the mortgagee or the purchaser may file a petition in equity in a court for the county where such foreclosure sale was held, for the confirmation of the foreclosure sale. The provisions of the laws of this State with respect to the commencing of proceedings in equity shall be complied with in all proceedings under this section. The petition shall set forth facts which show compliance with the provisions of section 33 of this act with respect to the conduct of the foreclosure sale. If the court, in term or in vacation, shall find that the provisions of this act with respect to the foreclosure sale set forth in section 33 of this act have been complied with at the foreclosure sale and that the foreclosure sale was regular in all respects, the court, in term or in vacation, as expeditiously as the ends of justice permit, shall enter a final order confirming the foreclosure sale. If the court shall find to the contrary, the court, in term or in vacation, as expeditiously as the ends of justice permit, shall enter a final order rescinding the foreclosure sale, with the effect provided in this article. Any such order confirming the sale may be recorded by the petitioner in each place where the foreclosed mortgage was recorded. 
b. If a petition for confirmation of foreclosure sale shall be made in accordance with the provisions of this section by the mortgagee, said petition may, at the option of the mortgagee, include an application for deficiency judgment as otherwise provided in this article.

c. The proceeding provided by this section shall be limited by the courts of this State to the determination of whether there have been violations of law in connection with the foreclosure sale. Such procecding shall not afford to the mortgagor any relief which was available to the mortgagor prior to the forcclosure sale.

e. If, within 30 days after a foreclosure sale conducted under the provisions of this article, the mortgagor tenders to the sheriff, in cash, a sum equivalent to the unpaid balance of the obligation plus all costs and expenses and the additional sum of Two and One Half Dollars as a fee for executing the certificate of redemption, the sheriff shall issue a certificate of redemption to the mortgagor in the following form: [Here follows the statutory form of redemption certificate.] ...

Such certificate of redemption shall have the same force and effect as to the mortgage redeemed as if the mortgagee therein had executed and delivered to the mortgagor a satisfaction in the form set forth in subsection $c$ of section 23 of this Act.

536. Deficiency Judgment. a. If at the foreclosure sale the mortgaged premises do not sell for a sum sufficient to satisfy the unpaid balance of the obligation secured by the mortgage plus statutory costs and expenses, the mortgagee may enforce the note evidencing the obligation for the deficiency, by a petition for confirmation of the foreclosure sale and by praying for the deficiency, within 30 days after the date of the foreclosure sale, or by an action on the mortgage note, if brought after 30 days after the date of the foreclosure salc, and in support of such petition or complaint shall make an affidavit that in the bona fide judgment of the mortgagee the mortgaged premises were sold at forcelosure sale for the fair market value of such premises, and that the mortgaged premises did not then have a fair market value at least equal to the unpaid balance of the obligation plus statutory costs and expenses. If an action to rescind a foreclosure sale is commenced in accordance with the provisions of this article, the mortgagce may petition in a cross bill for a deficiency judgment in accordance with the provisions of this section. If the purchaser shall file a petition for confirmation of foreclosure sale in accordance with the provisions of this article, the mortgagee may petition by intervention for a deficiency judgment in accordance with the provisions of this section. No suit or other action on the mortgage note to obtain a deficiency judgment shall be entertained by any court of this State, unless brought within 6 months after the date of the foreclosure sale and in accordance with the provisions of this section.

b. If the obligor shall fail, after service of said petition or complaint upon the obligor, duly to appear and answer said petition or complaint, the court, in term or in vacation, shall enter judgment forthwith for the mortgagee for the amount of the deficiency. If the obligor shall duly appear and answer, the court hearing such matter, in term or in vacation, shall determine without the aid of a jury, unless, when under the constitution of this State he is entitled thereto, the obligor shall demand a jury, whether in accordance with the provisions of this section any deficiency judgment may be entered and the amount thercof. If the court shall determine that the mortgaged premises wcre sold at the foreclosure sale for an amount equal to or less than the fair market value thereof at the time of the foreclosure sale, the court, in term or in vacation, as expeditiously as the ends of justice permit, shall enter a jucigment for the amount of the deficiency which shall be the difference between the fair market value of the mortgaged premiscs at the time of the foreclosure sale and the sum of the unpaid balance of the obligation plus statutory costs and expenses. If the court shall determine that the mortgaged premises were sold at the forcclosure sale for an amount greater than the fair market value thercof at the time of the forcelosure sale, the court, in term or in vacation, as expeditiously as the ends of justice permit, shall enter a judgment for the amount of the deficiency which shall be the difference between the foreclosure sale price and the sum of the unpaid balance of the obligation plus statutory costs and expenses.

\$37. Certificate of Sale. a. After 30 days have elapsed after the date of a foreclosure sale, except as hereinafter provided, the sheriff who conducted the foreclosure sale, if still in office, and otherwise his successor in offec, shall execute and deliver to the purchaser at the foreclosure sale a certificate of sale in the following form: [Here follows the statutory form of certificate of sale.] ... In the event an action to rescind a foreclosure sale has been commenced or a petition for confirmation of forcelosure salc has been filed in accordance with the provisions of this article, the certificate of sale shall not be exceuted until an order confirming the foreclosure sale has been entered by the court and such order has become final, and in no event until 30 days have elapsed after the date of the forcclosure sale. . . .

c. A certificate of sale grants, bargains, sells, releases and conveys unto the person named therein as the purchaser forever, the mortgaged premises described therein, subject to any prior encumbrances or liens, together with the improvements, hereditaments and appurtenances thereunto belonging or in any wise appertaining, and all the estate, rights and interest of the mortgagee and mortgagor in and to the 
mortgaged premises described in the foreclosed mortgage and of all other persons having any interest in the foreclosed mortgaged premises which were, at the time of the foreclosure sale, subordinate to the interest of the mortgagee therein, including all homestead and dower rights and all inchoate and contingent rights in and to said mortgaged premises, together with all fixtures and articles of personal property now or hereafter attached thereto or used in conjunction with said premises, to have and to hold the same unto said purchaser forever. Such certificate may be recorded in the same manner as deeds of real estate are recorded.

d. After the expiration of 7 days from the date of recordation of a certificate of sale, it shall be the duty of the sheriff to place the record holder of the certificate of sale in possession of the premises described in the certificate of sale and it shall be the duty of any court of record of this State to which the sheriff or the record holder of the certificate of sale may apply in term or in vacation to issue forthwith such writs of assistance or other orders as shall enable the sheriff to perform the foregoing duty. \$uch writ or orders shall be issued ex parte and without notice upon the presentation by the sheriff of the recorded certificate of sale or a certified copy thereof. . . .

\$38. Statutory Costs AND Expenses. a. Cost of foreclosure which shall be allowed to the mortgagee out of the purchase price on foreclosure sale are:

(I) The amount actually paid to cover the cost of recording, mailing and publishing the notice of forcelosure sale.

(2) The amount actually paid to the sheriff to cover all costs of the foreclosure sale.

(3) The amount actually paid to the sheriff to cover the cost of the certificate or certificates of sale.

(4) The amounts actually paid to place the certificate or certificates of sale on record, excluding the double charge for late recording prescribed in this article.

b. Other costs and expenses (exclusive of attorneys' fees for legal service in connection with court proceedings) shall in any event be allowed to the mortgagee in the following amounts:

(I) When the unpaid balance of the obligation secured by the mortgage which is foreclosed is $\$ 500$ or less, \$ro.

(2) When the unpaid balance of the obligation secured by the mortgage which is foreclosed is over $\$ 500$ but not over $\$ 1,000, \$ 20$.

(3) When the unpaid balance of the obligation secured by the mortgage which is foreclosed is over $\$ 1,000$ but not over $\$ 5,000, \$ 50$.

(4) When the unpaid balance of the obligation secureri by the mortgage which is foreclosed is over $\$ 5,000$ and not over $\$ 10,000, \$ 100$.

(5) When the unpaid balance of the obligation secured by the mortgage which is foreclosed is over $\$ 10,000$ and not over $\$ 20,000, \$ 150$.

(6) When the unpaid balance of the obligation secured by the mortgage which is foreclosed is over $\$ 20,000$, I per cent of the unpaid balance of the obligation, but in no event in excess of $\$ 500$.

The court, in proceedings under sections $32,34,35$ or 36 of this act, shall have power to allow as costs attorneys' fees in such amounts as it shall deem just and equitable. 